\title{
A novela Don Correa (1881) de Gottfried Keller: ficcionalização e mitificação de uma personagem histórica*
}

\author{
Maria Manuela Gouveia Delille1 \\ Universidade de Coimbra
}

Resumo: Integrada no ciclo narrativo Das Sinngedicht (1881) do escritor suíço Gottfried Keller, a novela Don Correa traça, de modo romanesco, uma biografia amorosa de Salvador Correia de Sá e Benevides (1602 -1681), célebre herói português das Guerras da Restauração do Brasil e da Reconquista de Angola aos Holandeses. Após salientar o ambiente teatral e fantasmagórico em que decorre o primeiro episódio da novela, consubstanciado na paixão funesta do protagonista por uma misteriosa fidalga alentejana e na transformação final do apaixonado amante em cruel justiceiro, a análise incide no enredo amoroso de final feliz entre D. Correia e a escrava africana Zambo, passado no vasto espaço do império colonial português seiscentista. Quanto a este segundo episódio, procura-se pôr em relevo não só a idealização da personagem histórica e o seu significativo envolvimento no mito de Pigmalião e Galateia, mas também a reserva crítica que transparece da elaborada construção ficcional kelleriana em relação ao discurso colonialista dominante na época.

Palavras-chave: História, Ficção, Mito

Zusammenfassung: Dem Erzählzyklus Das Sinngedicht (1881) des Schweizer Schriftstellers Gottfried Keller zugehörig, zeichnet die Novelle Don Correa auf romaneske Weise eine amouröse Biographie des durch die Restaurationskriege in Brasilien und die Rückeroberung Angolas aus der Hand der Holländer zu Berühmtheit gelangten portugiesischen Nationalhelden Salvador Correia de Sá e Benevides (1602-1681). Nach kurzer Herausstellung des theatralisch-phantasmagorischen Milieus, in dem die erste Episode abläuft, welche die 
unheilschwangere Leidenschaft des Protagonisten für eine geheimnisumwitterte Dame aus dem Alentejo und seine schließliche Verwandlung in einen grausamen Richter zum Inhalt hat, befasst sich die Analyse mit der verwicklungsreichen, glücklich endenden Liebesgeschichte zwischen Don Correa und der afrikanischen Sklavin Zambo, deren Schauplatz das weite portugiesische Kolonialreich des 17. Jahrhunderts ist. Mit Bezug auf diese zweite Episode soll nicht nur die hier erfolgte Idealisierung der historischen Figur und deren bedeutsame Einbindung in den Pygmalion-Galatea-Mythos, sondern auch die durch die elaborierte Keller'sche Konstruktion durchscheinende kritische Distanz gegenüber dem damals vorherrschenden kolonialistischen Diskurs hervorgehoben werden.

Schlüsselbegriffe: Geschichte, Fiktion, Mythos

Pertencente ao ciclo novelístico kelleriano Das Sinngedicht [0 Epigrama], 1881, Don Correa traça, de modo romanesco, uma biografia amorosa de Salvador Correia de Sá e Benevides (1602-1681), célebre herói português seiscentista das Guerras da Restauração do Brasil, que, em 1648, com a Reconquista de Angola aos Holandeses, atinge o auge da sua já tão prestigiada carreira política e militar (Figura 1).²

Antes de iniciar a análise, necessário se torna referir, de forma tão sumária quanto possível, a moldura narrativa em que esta e as outras seis novelas do ciclo se integram. ${ }^{3} \mathrm{~A}$ narração de fundo que constitui essa moldura começa por nos apresentar Reinhart, jovem cientista que amaldiçoa, qual segundo Doutor Fausto, a vida alienada a que até aí se autocondenara e resolve partir a correr mundo. Tomando como divisa um curioso epigrama do poeta barroco alemão Friedrich von Logau (1605-1655) -

Wie willst du weiße Lilien zu roten Rosen machen?

Küß eine weiße Galathee: sie wird errötend lachen. (Keller 1991:100)

[Como hás-de tu transformar lírios brancos em rosas vermelhas?

Beija uma Galateia branca: ela rirá com o rubor aceso nas faces. $]^{4}$

-, lança-se à procura da mulher que, ao ser beijada, satisfaça os dois requisitos enunciados: 
o riso e o rubor. 0 leitor ciente do significado de riso e rubor nas histórias amorosas da obra anterior de Keller facilmente entenderá, como Louis Wiesmann (1983: 310) faz notar, que o que Reinhart busca é a mulher perfeita, aquela em que naturalmente se equilibrem "Sitte und Sinnlichkeit" [recato e sensualidade], aquela em que exista a mistura paradoxal de pudor casto, reservado e reflectido, com uma natureza sensual, livre e aberta. Como é sabido, na visão antropológica kelleriana, é a síntese harmoniosa dos pares opostos "Sinnlichkeit/Sitte", "Natur/Kultur", "Freiheit/Bindung" [liberdade/vinculação] - que define o perfil ideal não só da mulher, mas da criatura humana em geral (Ermatinger6 1924: 592-593, 604-605, e Reichert 1964: 91).

No decorrer das suas deambulações, o protagonista da narrativa emoldurante de Keller, de modo análogo a um herói dos Märchen românticos, acaba por encontrar, no meio dum jardim de uma casa apalaçada, uma jovem belíssima, toda vestida de branco, ${ }^{5}$ que, segundo ele mais tarde vem a saber, se chama Lúcia e é a sobrinha dum velho coronel aposentado, antigo amigo de juventude dos seus próprios pais.

Encantado por aquele lugar e não menos pela anfitriã, na qual começa a entrever os traços da mulher que procura, Reinhart permanece aí alguns dias, vindo o tempo em grande parte a ser preenchido com uma série de histórias, ao todo sete, contadas alternadamente pelo protagonista, por Lúcia e pelo tio. Na maior parte dessas histórias vão-se iluminando, sob várias perspectivas, os problemas decorrentes de casamentos ou de ligações amorosas em que o homem é superior à mulher, ou diferente desta, no que toca à condição social, cultura, situação económica, raça ou credo religioso. Keller pensava dar a este ciclo narrativo o título de Galatea, ${ }^{6}$ e efectivamente quase todas as novelas nele incluídas constituem variações modernas, romântico-realistas, do conhecido mito clássico de Pigmalião e Galateia, com um acentuado pendor sociológico e pedagogizante, muito caro aos escritores alemães da segunda metade do século XIX. ${ }^{7}$

É na boca de Reinhart que surgem as três grandes narrativas - Regine, Die arme Baronin, Don Correa - em que o protagonista representa o papel de protector, quando não expressamente o de educador e pedagogo da amada, a quem liberta da miséria, da ignorância e/ou da escravidão. Por sua vez Lúcia, que se revela como uma jovem muito 
culta, de mentalidade livre e esclarecida, ${ }^{8}$ critica vivamente esta fixação da mulher no papel de criatura inferior, naturalmente submissa ao homem; através das novelas humorísticas e/ou burlescas que conta, ou dos comentários por vezes mordazes com que acompanha as histórias dos narradores masculinos, faz - sem cair nos excessos das feministas da época uma defesa equilibrada dos direitos, qualidades e capacidades do seu próprio sexo, obrigando Reinhart a reconhecer nela uma interlocutora convincente e cada vez mais atraente. Podemos pois dizer que a narração e/ou a análise progressiva dos vários casos amorosos é um meio de Reinhart e Lúcia se conhecerem melhor e de aprenderem a amarse, cumprindo-se, por fim, no beijo que firma o noivado, o sentido pleno do epigrama do início do ciclo.

Integrada neste contexto, a novela Don Correa, ${ }^{9}$ a última narrada por Reinhart, conquanto de forma alguma prescinda de uma apresentação heróica da figura enérgica de militar e político que foi Salvador Correia de Sá, empenha-se essencialmente na descrição das suas aventuras e desventuras amorosas, muito embora os dados biográficos históricos conhecidos sobre o famoso almirante nada nos digam a esse respeito, indicando-o apenas como esposo, aparentemente fiel, de uma rica viúva crioula, D. Catarina de Velasco, de quem teve seis filhos. ${ }^{10}$

Evidenciando uma estrutura claramente bipolar e antitética, a narrativa desdobra-se em duas partes distintas, separadas pela distância temporal de dez anos. Em cada uma delas descreve-se um caso amoroso passado com Correia de Sá, o primeiro dos quais termina tragicamente e o segundo tem um final harmonioso e feliz.

Na primeira parte o herói é descrito como homem que, tornado famoso pelos seus feitos militares, atingira, ainda muito novo, uma elevada e cobiçada posição política menciona-se expressamente o exercício do cargo de governador do Rio de Janeiro. Caído temporariamente em desgraça por intrigas invejosas, D. Salvador resolve, à semelhança do próprio narrador intradiegético, partir à procura da companheira da sua vida "ehe die Tage der Arbeit und des Kampfes zurückkehrten" (Keller 1991: 278) [antes que voltassem os dias de trabalho e de combate]. Vem então do Brasil para Lisboa e aí, durante um espectáculo teatral, fica deslumbrado com a beleza invulgar de uma jovem viúva aristocrata, 
D. Feniza Mayor do Cercal, que se apresenta toda vestida de negro, com um grande broche de rubis ao peito. Como orientação inequívoca de leitura, Keller faz o narrador Reinhart notar que, tal como no vestuário da dama, também nos trajes da pequena comitiva de criados que por toda a parte a acompanham predominam o vermelho e o negro (ibidem: 280). Nesta altura da sintagmática narrativa, o tradicional valor simbólico de tais cores sempre ligadas a naturezas e práticas diabólicas, ao sangue e à morte - deixa já antever ao leitor atento o carácter ominoso da beldade pela qual o ingénuo guerreiro se sente tão atraído.

Não fazendo caso dos boatos que circulavam sobre a referida senhora, apelidando-a de bruxa e aos seus servidores de espíritos demoníacos, Salvador Correia - que quer ser amado apenas pela sua própria pessoa e não pela sua fortuna ou pela categoria social a que pertence - segue e espia, ora disfarçado de pedinte, ora de marinheiro mouro, D. Feniza e os seus acompanhantes pelos vários locais a que a sociedade lisboeta do tempo costumava afluir. Como cenário do incipiente e estranho enredo amoroso, surge-nos assim a Lisboa católica, supersticiosa, exótica e cosmopolita, da primeira metade do século XVII - no tempo ainda da integração do reino de Portugal na Monarquia Hispânica -, com as suas igrejas, passeios públicos, teatros e hospedarias, estas últimas frequentadas, como o narrador expressamente refere (ibidem: 281), por navegadores e comerciantes de todas as partes do mundo.

A fase seguinte da intriga decorre nas propriedades de D. Feniza, no litoral do Baixo Alentejo, perto da povoação do Cercal, onde D. Salvador aparece fingindo-se vítima dum naufrágio e, sob a falsa identidade de um fidalgo de poucos haveres, não tarda a contrair matrimónio com a misteriosa dama. No castelo à beira-mar o casal vive cerca de meio ano, em prolongada lua-de-mel, que o narrador muito significativamente compara à estada de Ulisses na ilha de Calipso (ibidem: 288). De regresso temporário a Lisboa, Correia de Sá é nomeado vice-almirante e incumbido pelo rei de desempenhar importante missão política e militar no Brasil. Só então se decide a confessar à mulher o seu segredo; porém, quando volta ao castelo do Cercal, onde entretanto a deixara com os criados, sem explicar a razão do seu afastamento e ausência, revelam-se baldados todos os seus esforços para a 
convencer da sua verdadeira identidade e para a levar a partir consigo no luxuoso navio almirante que os aguardava. Semelhante a uma Fúria, D. Feniza encarcera o marido numa das salas da torre, após o que ela e o séquito - que o narrador designa como demónios incendeiam o castelo, pondo-se imediatamente em fuga. Apenas a muito custo D. Correia consegue libertar-se e regressar ileso aos navios da sua esquadra, onde no dia seguinte, perante um tribunal militar, todos os culpados do incêndio e do atentado à sua pessoa são julgados e condenados à morte por enforcamento, vindo também a provar-se que D. Feniza mandara estrangular o primeiro marido e fora infiel a Salvador Correia quando da ausência deste em Lisboa. No melodramático desfecho da história vemos assim transformado em homem de Estado e juiz implacável o apaixonado, ingénuo e cego, que julgara erradamente poder atingir o verdadeiro amor através das artes do fingimento. ${ }^{11}$

Repare-se também que durante a narração de toda a fantástica intriga amorosa passada no Portugal seiscentista sob o poderio filipino, Reinhart atribui a D. Feniza um papel claramente negativo, ao passo que procura justificar e/ou atenuar os erros de D. Correia, ${ }^{12}$ vendo-o sempre com simpatia e até muitas vezes com admiração. No entanto, quase no final (ibidem: 301),13 não só a descrição do colapso físico e psíquico da fidalga alentejana é susceptível de ganhar para ela a compaixão do leitor, como também se torna muito relativizador aquele passo em discurso indirecto livre no qual a voz do narrador conflui com a do protagonista ao perguntar a quem seria de atribuir a maior culpa quanto ao rumo desastroso da história: a D. Feniza, por não ter pressentido a verdadeira natureza do homem que tomara por esposo, ou ao almirante, por não ter sabido reconhecer o lado bestial e demoníaco da mulher que conquistara?

Efectivamente, como bem faz notar Wolfgang Preisendanz (1977: 189-190), toda esta primeira parte da intriga decorre sob o signo do parecer, que oculta o verdadeiro ser, e nesse mundo de aparências e embustes, para o qual o almirante muito contribuiu com o seu disfarce, não pode vingar uma equilibrada relação amorosa. A este respeito julgo conter valor simbólico e indicial o espaço em que se desenrola o primeiro encontro entre D. Salvador e D. Feniza: o teatro, lugar por excelência de jogo, ilusão, fingimento.

Ao contrário desta paixão funesta pela senhora do Cercal, que, segundo Jonas 
Fränkel (Keller 1934: 473-474), deve ser da inteira invenção do autor suíço, no enredo amoroso de final feliz da segunda parte misturam-se factos reais da vida de Salvador Correia de Sá - os altos cargos exercidos no Brasil, a reconquista de Angola aos Holandeses em 1648, a sujeição de reis africanos, o tempo pacífico de governação em terra angolana com factos semi-históricos ou semilendários passados com dois navegadores portugueses também portadores do apelido Correia.

Um deles é João Correia de Sousa, governador de Angola entre 1621 e 1623, a respeito do qual a história e a lenda referem uma célebre audiência concedida em 1622 à princesa Zinga, meia irmã e embaixadora do rei negro Ngola Bandi (Figura 2). ${ }^{14} \mathrm{Na}$ obra Istorica Descrizione de' tre' regni Congo, Matamba et Angola do missionário capuchinho italiano Giovanni Antonio Cavazzi da Montecuccolo (1621-1678), publicada pela primeira vez em Bolonha em 1687, reeditada em Milão em 1690 e traduzida para a língua alemã através do francês em 1694 (Figura 3), que muito provavelmente terá sido, na versão alemã, uma importante fonte da novela kelleriana, encontram-se um relato pormenorizado e uma gravura ilustrativa da referida entrevista (Figura 4). ${ }^{15}$ Nesse relato se conta como Zinga, em sinal de protesto por o governador português lhe ter oferecido como assento apenas duas almofadas colocadas no chão, em cima do tapete, à frente da cadeira imponente que ele próprio ocupava, ordenou a uma das escravas da sua comitiva que se ajoelhasse com os braços apoiados à frente e, sentando-se sobre as costas dobradas da serva, i.e., elevando-se ao nível do interlocutor, negociou dessa cadeira humana, com energia e grande habilidade diplomática, o tratado de paz desejado pelo irmão.

O outro navegador é Diogo Álvares Correia (?-1557), que, passados mais de dois séculos sobre a sua morte, nos surge como protagonista do poema épico Caramuru (1781) de Frei José de Santa Rita Durão (Figura 5); a lenda e a epopeia atribuem a esse aventureiro quinhentista um naufrágio em costas brasileiras (perto da Baía de Todos os Santos) e uma ligação amorosa com a bela índia Paraguaçu, que o acompanha numa viagem a França, país em que se celebra primeiro o baptismo da noiva e depois o casamento do par, sendo padrinhos os próprios reis franceses, Henrique II e Catarina de Médicis. ${ }^{16}$ Do poema brasileiro Caramuru foi publicada em Paris, em 1829, uma tradução francesa de Eugène de 
Monglave sob o título de Caramourou ou La découverte de Bahia, roman-poème brésilien,17 tradução essa que o novelista suíço pode muito bem ter conhecido. ${ }^{18}$

Fundindo, portanto, dados históricos e lendários de figuras e épocas diversas, Gottfried Keller constrói, na segunda metade da novela Don Correa, a intriga amorosa entre Salvador Correia de Sá e a escrava africana Zambo, a qual constitui uma variação do mito de Pigmalião e Galateia, transportada para o espaço do império colonial português seiscentista. A escolha, nesta fase da acção, de um cenário predominantemente angolano releva da sintonia do autor com o gosto dos leitores do século XIX; nessa época por excelência das grandes viagens e da colonização africanas, nota-se nos vários países europeus, sobretudo nos de maior potência económica, um interesse crescente pelo continente negro, tornando-se este, a nível literário, objecto de muitos relatos de viagens, de romances e de toda a sorte de obras históricas, geográficas e etnológicas.

No início desta parte africana da novela, depara-se-nos, cheia de colorido exótico, a narração da chegada da princesa angolana Annachinga a Luanda e, logo a seguir, a da sua entrevista com o governador português, que Keller muito possivelmente terá recriado a partir da obra já citada do missionário Cavazzi ${ }^{19}$ e talvez também da leitura de um livro de viagens alemão de inícios do século XIX, da autoria de Eberhard A. W. Zimmermann, em que se conta idêntica história. ${ }^{20} \mathrm{Em}$ ambas as fontes apontadas, a cena passa-se em 1622, não sendo o protagonista Salvador Correia de Sá, mas sim o seu já referido antecessor João Correia de Sousa.

Na novela de Keller, a princesa-embaixadora Annachinga só depois de passar por conversações prévias com um grupo de dignatários e oficiais superiores, numa primeira sala do pavilhão-mor dos conquistadores, é que vem a ser recebida no luxuoso aposento onde Salvador Correia de Sá se encontra, sentado em trono elevado e trajando as vestes militares dos dias de gala. Como irmã dum rei conhecido pela sua crueldade e selvajaria, do qual os portugueses, após alguns recontros armados, esperavam obediência e submissão, élhe apontada como assento apenas uma almofada vermelha, colocada no chão, a certa distância do trono do almirante. Numa indignação muda, a princesa africana chama com um aceno uma das suas escravas, e é esta que, de joelhos e com os braços no solo, forma, na 
atitude de uma esfinge egípcia, a cadeira na qual a sua ama se senta altiva e digna durante toda a audiência. D. Salvador, no decurso das negociações, vê-se obrigado a reconhecer numa mulher, e numa mulher de outra raça, uma interlocutora enérgica e avisada, que o desafia em pé de igualdade e que à saída, em gesto de inaudita sobranceria, lhe chega mesmo a oferecer o assento humano que a arrogância descortês dele a levara a improvisar:

Als (...) die Anwesenden dem Ausgange zuschritten, bemerkte Don Correa, daß die kniende Sklavin unbeweglich liegen blieb, und machte lächelnd die Fürstin aufmerksam, daß sie vergesse, ihren lebendigen Feldstuhl mitzunehmen.

"Ich setze mich nie zum zweiten Male auf denselben Stuhl", antwortete sie ohne zurückzublicken. "So mag er dem Hause bleiben, in welchem ich mich seiner bedient habe. Ich schenke Dir diese Person!" (Keller 1991: 308)

[Quando os presentes se dirigiam para a saída, Dom Correia notou que a escrava ajoelhada permanecera imóvel no mesmo lugar, e a sorrir lembrou à princesa que ela se estava a esquecer de levar a sua humana cadeira dobradiça.

"Nunca me sento segunda vez na mesma cadeira", respondeu ela sem olhar para trás. "Que fique pois na casa onde me servi dela. Ofereço-te esta criatura!"]

Repare-se que, no passo correspondente da narrativa de Cavazzi, seguido aliás muito de perto por Keller, não há referência expressa ao facto de Zinga ter oferecido a escrava ao governador: 21

Nach vollenden Gespräch / als der Statthalter bey jhr stunde selbe begleitend / hat er sie höfflich ermahnet / daß jene Hof-Dama sich noch nicht von ihrem Orth bewögte / deme sie / weilen sie sich mit Fleiß dises Funds gebrauchte / antwortete / daß sie jene ihr Dienerin nit daselbsten liesse aus Unbedachtsambkeit / sondern weilen es einer Abgesandtin ihres Königs übel anständig seyn wurde / das andere mahl sich nidersetzen / wo sie das erste mahl gesessen; weilen es in andern Begebenheiten an dergleichen Sesslen nicht ermanglen wurde / fragte dahero derselben nicht nach / noch wolte sie ferners für die jhrige erkennen. (Cavazzi 1694: 678)

[Concluída a audiência, o governador, ao acompanhá-la à saída, lembrou-lhe cortesmente que aquela dama de honor ainda não se movera do seu lugar, ao que ela, aproveitando com presteza o ensejo, respondeu que não deixava aquela sua serva ali por descuido, mas sim porque ficaria mal à 
embaixadora do seu rei sentar-se segunda vez na mesma cadeira; e, como em outras ocasiões não haveria falta de cadeiras semelhantes, não queria saber dela nem a reconhecia mais como sua.]

Observando a concentração dramática própria do género novelístico, Gottfried Keller utiliza a história anedótica da audiência a Annachinga para, a partir dela, desencadear a acção principal, pois o assento improvisado pela princesa angolana, e por ela ostensivamente abandonado e oferecido ao anfitrião, é nem mais nem menos que a escrava Zambo, de quem o almirante fará sua mulher. Assim se cria nesta cena teatral - em que o elemento proxémico assume fundamental importância - uma forte ambivalência na apresentação do relacionamento entre o governador português e a embaixadora angolana com quem ele se defronta. Por um lado, Salvador Correia de Sá recua, na sua estratégia de poder, perante uma mulher negra de estirpe régia, que, começando por não admitir ser colocada numa posição inferior, vem a replicar às suas tentativas de intimidação com a ameaça de sangrentas represálias sobre os prisioneiros portugueses detidos na corte do rei seu irmão; por outro lado, devido ao novo desenvolvimento que Keller dá ao confronto dramático, D. Correia, “obgleich gegen Sklaven und farbige Menschen gleichgültig und verhärtet wie die ganze gebleichte Welt" (Keller 1991: 309) [não obstante indiferente e endurecido, como todo o mundo descorado, em relação a escravos e gente de cor] reproduzo palavras do narrador intradiegético, as quais, ao caracterizarem a raça branca como uma raça descorada (leia-se também desvitalizada, dessorada, degenerada), contêm uma crítica irónica às suas pretensões de superioridade -, acaba em termos de acção por ser engrandecido, impondo-se à simpatia do leitor, porque, em manifesta oposição à atitude sobranceira e cruel de Annachinga no que toca a Zambo, vai no final da entrevista levantar a escrava do chão, tomá-la nos braços e beijá-la docemente em ambas as faces, vai tratar como um ser humano digno de ser amado aquela que a princesa africana usara como mero objecto desprezível, e que, segundo os conselhos por ela própria dados ao almirante, deveria ser ensinada à força de chicote. ${ }^{22}$

Registe-se ainda que no decurso da novela, relativamente à descrição física das personagens africanas, se verifica, como Sabine Doering (2007: 51) aponta, uma preferência notória pelas figuras femininas, uma declarada feminização da raça negra, pois só 
Annachinga e Zambo/Maria são individualizadas, só a elas e muito especialmente a Zambo é dedicada uma descrição pormenorizada tanto da sua aparência física como moral. Ao contrário de Annachinga, sempre caracterizada com o adjectivo "schwarz", a escrava Zambo, com a sua cor de pele morena clara, cabelos não encarapinhados mas lisos e macios e uma fisionomia nobre, que o narrador compara ao talhe de rosto das mulheres do antigo Egipto, não é de forma alguma um tipo de beleza negróide; de ar grácil e distinto, acentua-se a respeito do seu ser a humildade e a inocência, a completa inexperiência nas relações amorosas e sociais, o seu estatuto de "Naturkind" [ser natural] - acusando Gottfried Keller neste aspecto a tendência, já notada por Herbert Uerlings (2001: 47) noutras obras coloniais, de representar a figura do 'bom selvagem' por tipos não negróides. Como Bernd Neumann (1982: 255) pertinentemente anota a este propósito, G. Keller, apesar de todo o seu esclarecimento crítico, não transpõe "die koloniale Grenze" [a fronteira colonial], i. e., não apresenta o amor e casamento entre um branco e uma negra, mas atribui à escrava Zambo uma ascendência oriental, ${ }^{23}$ que se reflecte no tom moreno claro da pele e manifestamente a aproxima do ideal de beleza feminina do homem europeu (e da branca Galateia, capaz de se ruborizar, do epigrama de Logau). ${ }^{24}$

Na parte final da novela, com o propósito secreto de vir a desposar a jovem pagã, D. Correia manda-a baptizar ${ }^{25}$ e imediatamente a seguir prepara tudo para que ela seja educada num convento de dominicanas brasileiro dirigido por uma abadessa, sua tia. Antes, porém, de conseguir embarcar Zambo/Maria, vê-se obrigado a defendê-la da perseguição dos missionários jesuítas, que - apresentados como fanáticos intolerantes e exploradores da superstição e crendice populares - se mostram apostados em exibir a escrava como neófita cristã miraculada, a quem Deus teria aparecido na imagem da Virgem Maria, precisamente na hora do baptismo.

Mesmo no convento brasileiro a jovem não escapa ao zelo fanático dos seus perseguidores. Depois de muitas peripécias mirabolantes e de viagens de longo curso, que levam os protagonistas desta novela a movimentar-se com extrema facilidade entre Angola, Brasil e a Península Ibérica (no fundo as rotas do intenso comércio de escravos praticado na época), Maria foge dum convento de dominicanas em Cádis, onde os jesuítas a tinham 
sequestrado, e vem por seu próprio esforço e vontade ter ao palácio de D. Salvador em Lisboa. Aí se celebra a boda, e o casal parte de novo para África. Durante a travessia, é o próprio almirante que, revivendo o mito de Pigmalião, enceta a tarefa, menosprezada pelas religiosas dominicanas e pelos jesuítas, de educar a antiga escrava segundo os princípios da liberdade e da responsabilidade de uma esposa cristã.

No diálogo com que fecha a novela, Maria, absorta na contemplação do oceano, e porventura preocupada com os ensinamentos do marido sobre a liberdade da alma humana, pergunta-lhe:

"Hat das Meer auch eine Seele und ist es auch frei?" (...)

"Nein", antwortete Don Correa, "es gehorcht nur dem Schöpfer und den Winden, die sein Atem sind! Nun aber sage mir, Maria, wenn Du ehedem Deine Freiheit gekannt hättest, würdest Du mir auch Deine Hand gereicht haben?"

"Du frägst zu spat", erwiderte sie mit nicht unfeinem Lächeln; "ich bin jetzt Dein und kann nicht anders, wie das Meer!"

Da sie aber sah, daß diese Antwort ihn nicht befriedigte und nicht seiner Hoffnung entsprach, blickte sie ihm ernst und hochaufgerichtet in die Augen und gab ihm mit freier und sicherer Bewegung die rechte Hand. (Keller 1991: 331)

[“Também o mar tem alma, e também ele é livre?" (...)

"Não", respondeu Dom Correia, "obedece apenas ao Criador e aos ventos que são o seu hálito. Mas diz-me, Maria, se anteriormente tivesses conhecido a liberdade, ter-me-ias dado também a tua mão?"

"A tua pergunta vem demasiado tarde", respondeu ela com um sorriso a que não faltava finura; "agora sou tua e não posso fazer senão como o mar!"

Vendo, porém, que essa resposta o não satisfazia e que não correspondia ao que ele esperava, fitou séria e aprumada os olhos nos do marido e estendeu-lhe a mão direita num gesto livre e seguro.]

Se, quanto à relação senhor/escrava, marido/mulher, o diálogo propriamente dito entre D. Correia e Zambo/Maria não se mostra isento de ambiguidade 26 - repare-se na subtileza da resposta de Maria - , as linhas finais que se lhe seguem, com o seu enfático ritmo binário, parecem relevar por parte da jovem africana a sua interiorização dos valores da liberdade e da responsabilidade recém-aprendidos, ${ }^{27}$ apontando, como Axel Dunker 
(2008: 124) argutamente observa, para uma espécie de colonialismo 'iluminista', que se encontra subjacente nesta novela à figura do governador português.

Sem negar razão a Bernd Neumann (1982: 254-256) quando este afirma que no universo imperialista e ultra-católico da novela Don Correa a mulher se divide em duas imagens antinómicas - a mulher-bruxa, demoníaca e devoradora de homens, que é D. Feniza, e a mulher de modelo mariano, protagonizada pela escrava africana -, imagens essas que representam a relação perturbada com a sexualidade que continuará a marcar a civilização ocidental cristã nos séculos posteriores, ${ }^{28}$ julgo, no entanto, que a figura de Zambo/Maria, apesar da evidente idealização, não se pode considerar uma "Heilige" [santa]; parece-me neste ponto haver, no comentário desenvolvido pelo referido crítico, uma atribuição abusiva à jovem escrava de características que só o zelo fanático dos jesuítas lhe pretendem conferir, omitindo-se por completo o facto de ser o próprio D. Correia que a vem libertar desses enredos beatificantes. 0 relacionamento de Zambo/Maria com o almirante português, marcado aliás desde o início por uma nítida componente erótica (Keller 1991: 309), não constitui unilateral sublimação do instinto sexual, mas manifesta-se no termo da narrativa como a união equilibrada dos pares opostos "Sinnlichkeit/Sitte", "Natur/Kultur", "Freiheit/Bindung" - que se encontram em conflito no conjunto do ciclo Das Sinngedicht. 29

Quanto a Salvador Correia de Sá, a imagem que dele sobressai ao longo da segunda parte da narrativa revela-se predominantemente positiva: no campo político e militar surge como um grande e poderoso senhor, e na conquista amorosa como um homem enamorado, compassivo e tolerante, que defende a escrava africana - por um lado, contra a crueldade da princesa negra, por outro, contra o zelo fanático e intolerante dos jesuítas. Note-se que é completamente ignorada a sua acção como alto representante da coroa de Portugal no incremento do comércio de escravos angolanos e seu transporte para os territórios coloniais brasileiros; ${ }^{30}$ no discurso ficcional criado por Keller, D. Salvador vem a desempenhar, muito pelo contrário, o papel de libertador e educador de Zambo/Maria, papel esse acentuado - ou melhor, sublimado - pela sua identificação com a figura mítica de Pigmalião. 
Embora haja, nesta segunda parte de Don Correa, uma idealização e clara mitificação da personagem de Salvador Correia de Sá, não é de mais lembrar que pela relevância conferida à teatral entrevista com Annachinga se coloca expressamente em pé de igualdade a capacidade de negociação e a habilidade diplomática dos dois representantes políticos e que, em vários passos da narrativa, Keller põe na boca do seu narrador intradiegético algumas notas de ironia crítica que infirmam esquemas dicotómicos característicos do discurso colonial relativos à oposição superioridade / inferioridade entre a raça branca e a raça negra, ou entre colonizador e colonizado. 31 Para além disso, se atendermos ao posicionamento da novela dentro do ciclo Das Sinngedicht, verificamos que à história amorosa heroicizante e mitificante entre D. Correia e a escrava Zambo de imediato se contrapõe, contada por Lúcia, a novela burlesca e desmitificadora Die Berlocken [Os Berloques] (cf. Hart, 1996: 133, nota 2), na qual o jovem capitão francês Thibaut de Vallormes, participante na Guerra da Independência da América do Norte, manifesta um grande entusiasmo e fervor rousseauiano no encontro com a população índia, vindo a apaixonar-se pela bela indígena Quoneschi; numa ignorância total da língua e dos costumes da tribo a que a jovem pertence, mas plenamente convicto das suas próprias artes de sedução (já comprovadas em anteriores aventuras amorosas tidas em França), Thibaut não entende que o interesse que a índia por ele demonstra visa muito especialmente a obtenção dos valiosos berloques pendentes da corrente do seu relógio; perante os insistentes olhares e gestos de súplica, acaba por lhos oferecer na esperança ilusória de a conquistar definitivamente e no dia seguinte, durante um banquete festivo, com a amada sentada a seus pés e acariciando-lhe as costas nuas, julga-se - no dizer irónico-mordaz da narradora Lúcia - "der Christofor Columbus (...), welchem sich der entdeckte Weltteil in Gestalt eines zarten Weibes anschmiegt" (ibidem: 345) [o Cristóvão Colombo (...), a quem o continente descoberto se aconchega amorosamente na forma de uma terna mulher]; porém, no final da refeição, quando os homens da tribo executam frente aos hóspedes europeus uma dança guerreira, vê estupefacto as preciosas jóias que oferecera à sua suposta conquista penduradas no nariz dum possante índio, o noivo de Quoneschi, que no final da dança arrebata a jovem e com ela para sempre desaparece. ${ }^{32}$ 
Concluindo: a ficção narrativa de Gottfried Keller sobre uma personagem histórica portuguesa célebre pelos seus feitos militares em mar e terra e pela sua acção política, embora mantendo como pano de fundo o referido perfil deste herói e o cenário geopolítico em que se moveu, cria a seu respeito - sem qualquer pretensão de veracidade histórica uma biografia amorosa muito própria. No tempo da juventude, durante a fantástica aventura com D. Feniza e a estada, já após o casamento, no castelo do Cercal, não obstante a narração empática e benevolente de Reinhart, vemos o protagonista alimentar ilusões e cometer erros que mostram bem a sua inexperiência e vulnerabilidade, e também os preconceitos e atitudes típicos do homem da época, aos quais hoje chamaríamos machistas; a impressão global desta primeira parte reveste-se ainda de manifesta ambivalência se tivermos em conta a transformação abrupta, na fase final, do jovem conquistador, inseguro e ingénuo, num imponente e austero homem de Estado e sobretudo num juiz implacável e desumano da mulher que fora em grande parte vítima do seu jogo de ocultação e mentira. Ao longo da segunda metade da novela, D. Correia, que o narrador intradiegético continua a tratar com manifesta simpatia, revela-se uma personalidade plenamente amadurecida: tanto na acção política e militar, em que demonstra ser enérgico e destemido e, ao mesmo tempo, prudente e ponderado, como no idílio amoroso com Zambo/Maria, durante o qual surge como um homem apaixonado e esclarecido, que consequentemente se empenha em educar, segundo os princípios da liberdade e da responsabilidade de uma esposa cristã, a antiga escrava com quem se aliara pelo matrimónio.

Ao inserir assim a personagem histórica de Salvador Correia de Sá num tecido ficcional a vários títulos romanesco, e ao intensificar, na segunda parte da narrativa, essa ficcionalização pela envolvência na história mítica de Pigmalião e Galateia, Gottfried Keller desenha um retrato fortemente idealizado do conquistador-colonizador português, não deixando, porém, de questionar, através da complexa encenação literária que constrói, alguns estereótipos do discurso colonialista europeu dominante na época. Podemos pois considerar a biografia amorosa apresentada na novela Don Correa do ciclo kelleriano Das Sinngedicht um curioso exemplo de 'alteridade estética', para usar uma designação que hoje se aplica nos estudos interculturais a este tipo de ficção. 


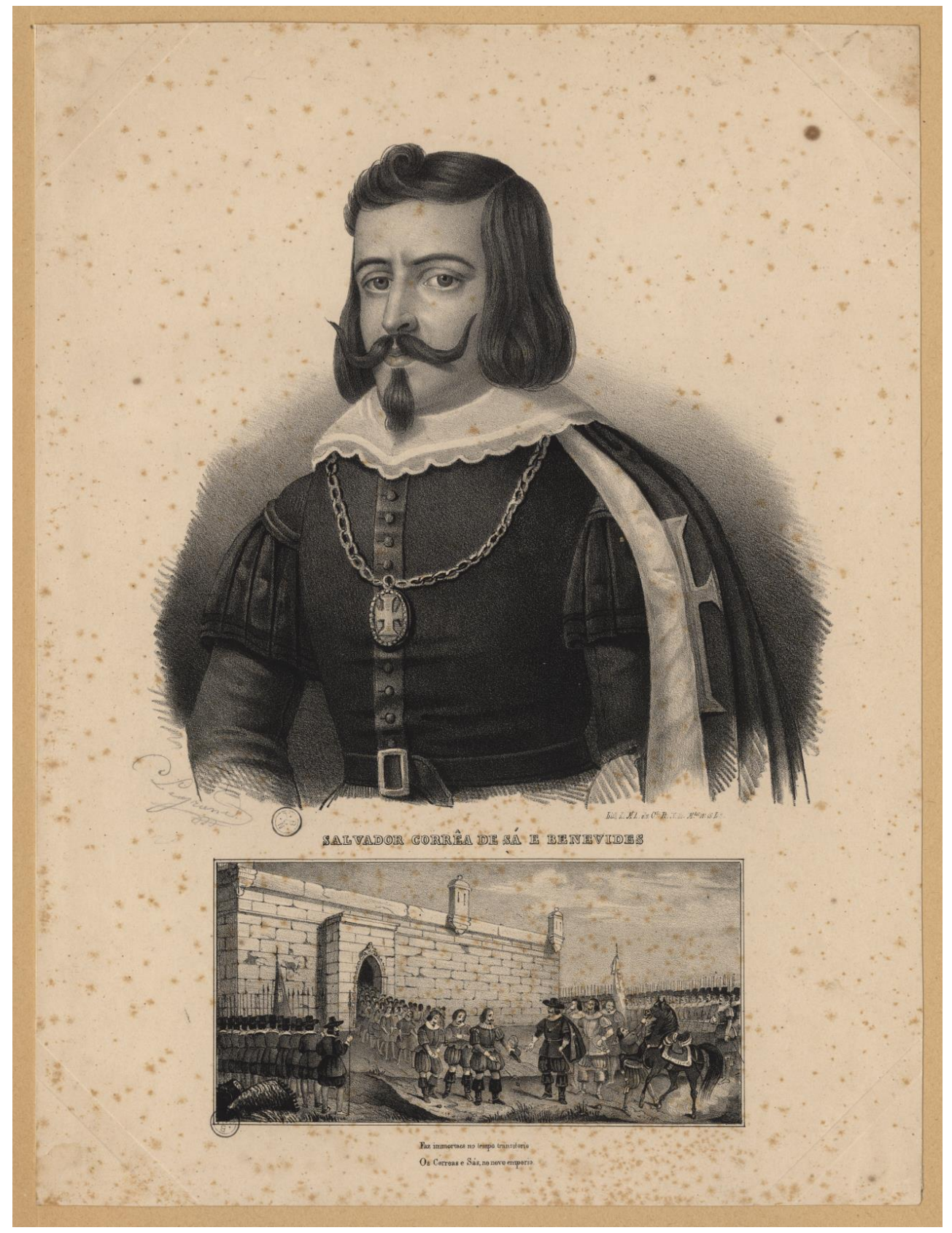

Figura 1 - Salvador Correia de Sá e Benevides.

Gravura de Charles Legrand / Litografia de Manuel Luiz.

Lisboa, 1841.

(Biblioteca Nacional de Portugal) 


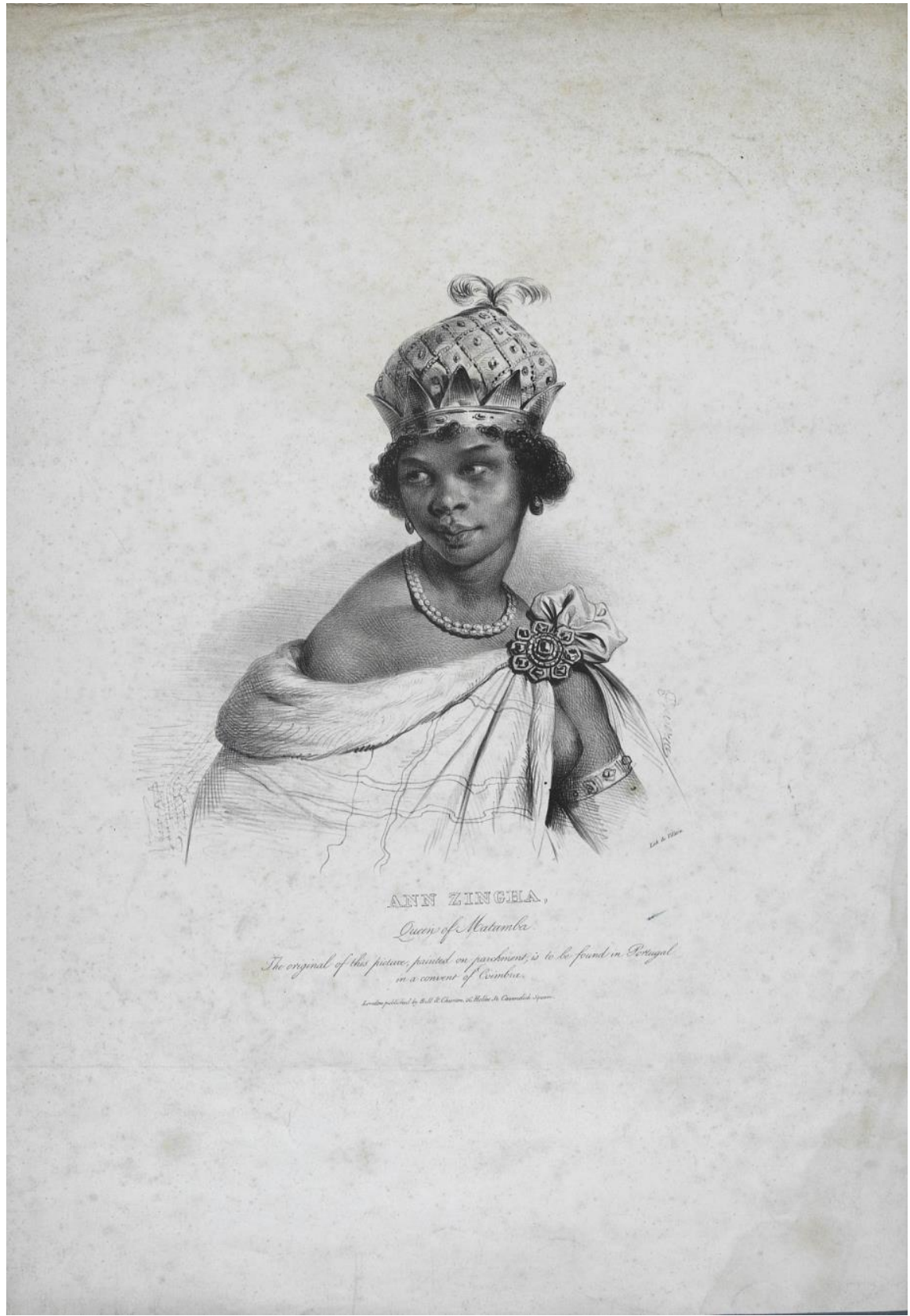

Figura 2 - Zinga, aliás Ginga Bandi, rainha de Matamba e Angola.

Gravura de Achille Deveria. London, Bull \& Churton [ca. 1830].

(Biblioteca Nacional de Portugal) 


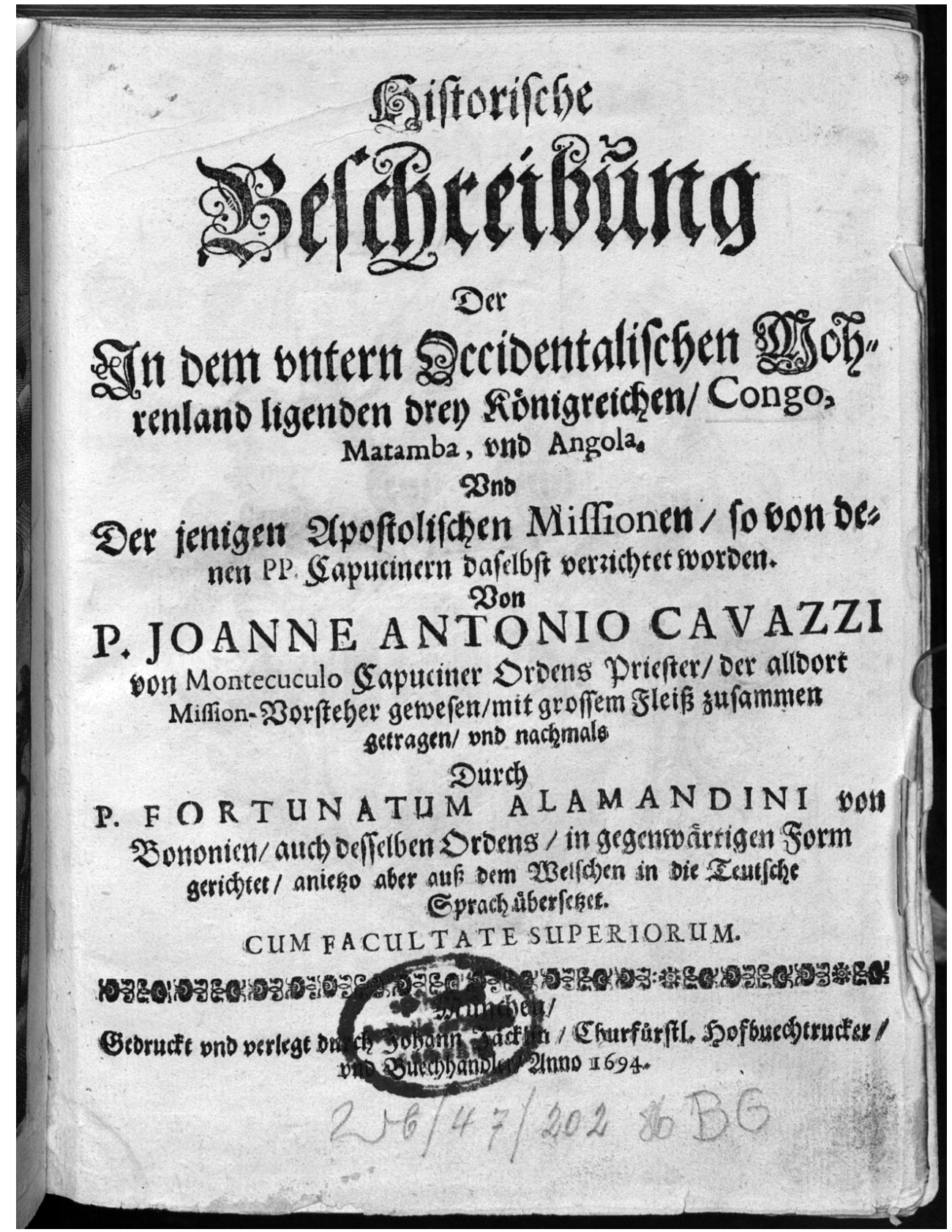

Figura 3 - Frontispício da obra Historische Beschreibung der in dem untern Occidentalischen Mohrenland ligenden drey Königreichen Congo,

Matamba, und Angola. (...) von P. Joanne Antonio Cavazzi von Montecuculo (...).

München / Gedruckt und verlegt durch Johann Jäcklin (...) Anno1694.

(Bayerische Staatsbibliothek München) 


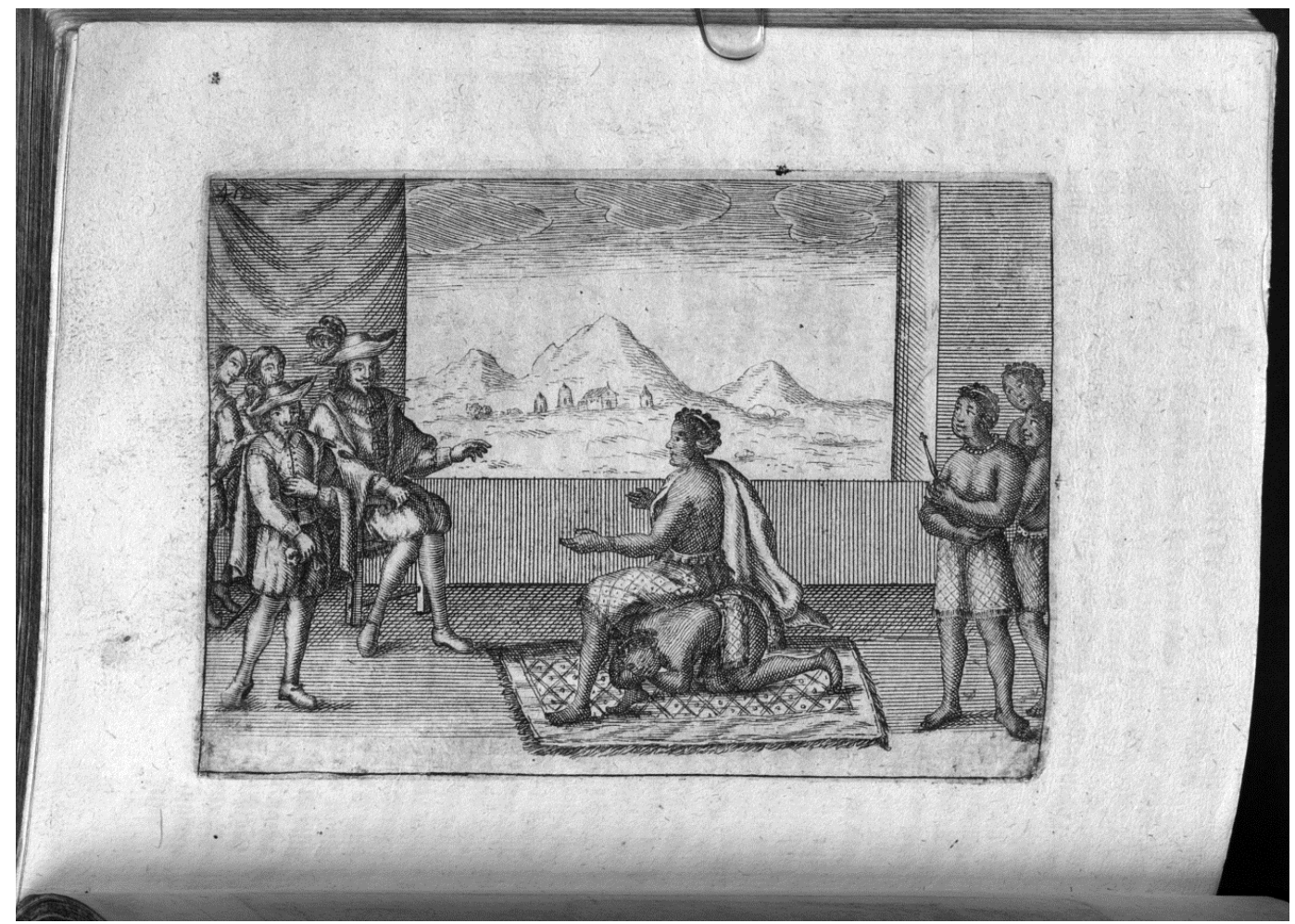

Figura 4 - Entrevista da princesa Zinga Bandi com o governador de Angola João Correia de Sousa.

In: P. Joanne Antonio Cavazzi von Montecuculo, Historische Beschreibung der in dem untern Occidentalischen Mohrenland ligenden drey Königreichen Congo, Matamba, und Angola (...), München, 1694, p. 676.

(Bayerische Staatsbibliothek München) 


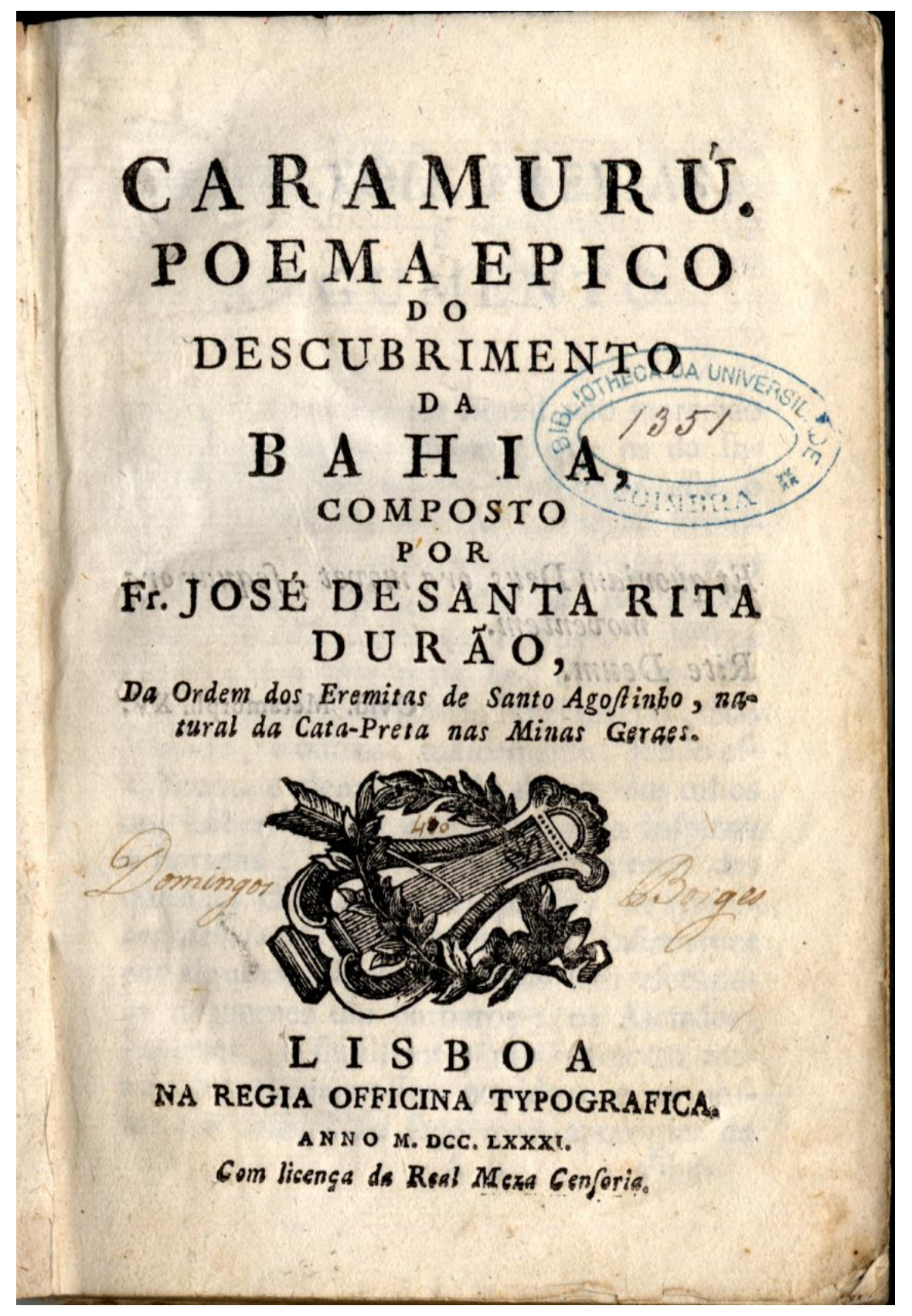

Figura 5 - Frontispício do poema épico Caramuru de José de Santa Rita Durão. Lisboa, Régia Oficina Tipográfica, 1781.

(Biblioteca Geral da Universidade de Coimbra) 


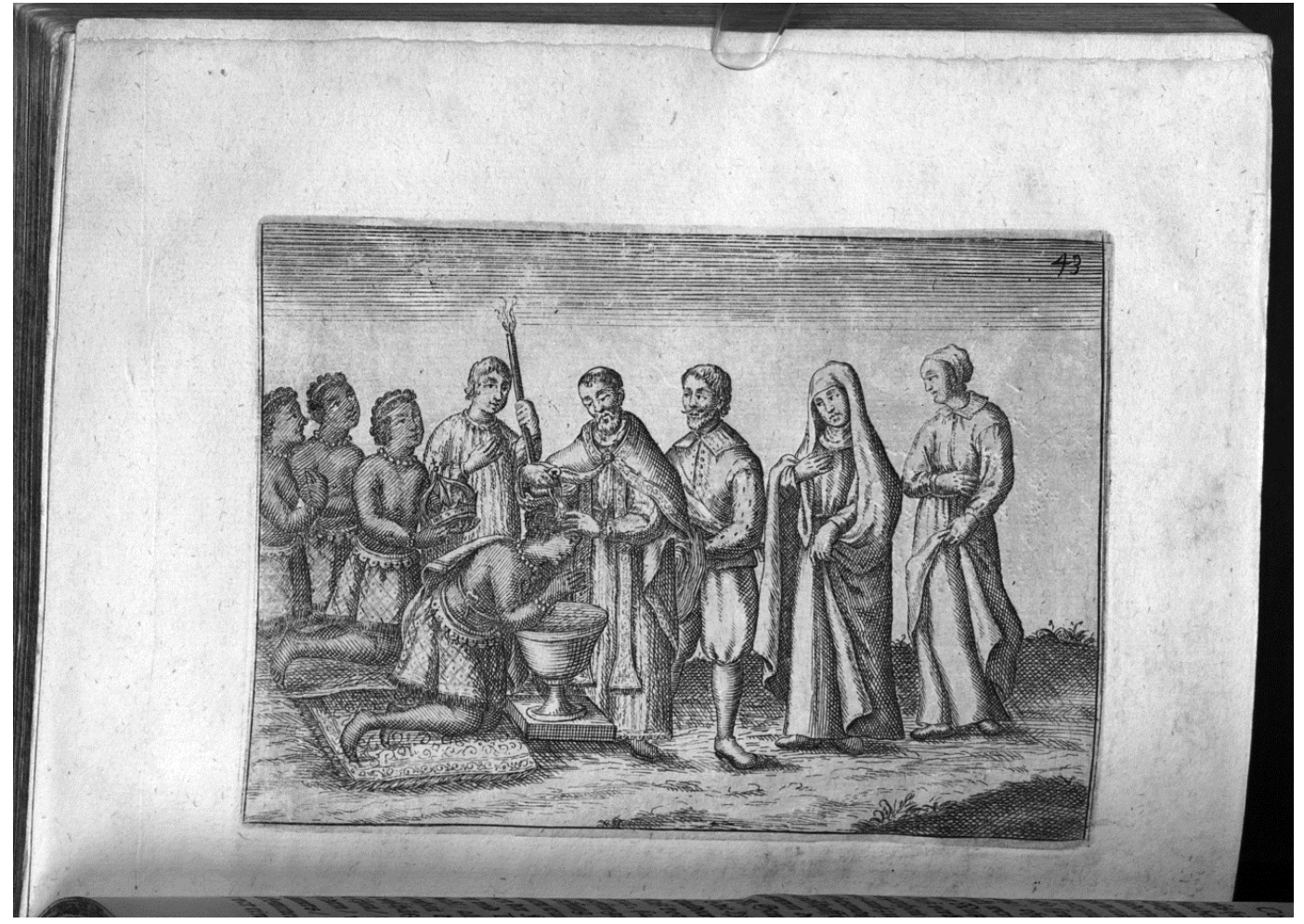

Figura 6 - Baptismo da princesa Zinga Bandi em Luanda.

In: P. Joanne Antonio Cavazzi von Montecuculo, Historische Beschreibung der in dem untern Occidentalischen Mohrenland ligenden drey Königreichen Congo, Matamba, und Angola (...), München, 1694, p. 678.

(Bayerische Staatsbibliothek München) 


\section{Bibliografia}

Agualusa, José Eduardo (2014), A Rainha Ginga. E de como os africanos inventaram o mundo, Lisboa, Quetzal.

Almeida, Luís Ferrand de (1959) e (1960), "A data da morte de Salvador Correia de Sá", Revista Portuguesa de História, tomo VIII, 327-330, e respectiva Addenda Corrigenda, Revista Portuguesa de História, tomo IX, 350-35.

Amrein, Ursula (2007), “Das Sinngedicht. Novellen. Anthropologie nach Säkularisierung“, in Walter Morgenthaler (ed.), Gottfried Keller. Romane und Erzählungen, Stuttgart, Philipp Reclam jun., 134-153.

Anton, Herbert (1970), Mythologische Erotik in Kellers "Sieben Legenden" und im "Sinngedicht", Stuttgart, Metzler.

Aurnhammer, Achim / Martin, Dieter (eds.) (2003), Mythos Pygmalion. Texte von Ovid bis John Updike, Leipzig, Reclam.

Boxer, Charles Ralph (1952), Salvador de Sá and the Struggle for Brazil and Angola 16021686, University of London, The Athlone Press.

-- (1990), "Salvador Correia de Sá e Benevides", in Dicionário de História de Portugal dirigido por Joel Serrão, vol. V, Porto, Livraria Figueirinhas, 400-401.

Cadornega, António de Oliveira de (1940) História Geral das Guerras Angolanas. Anotado e corrigido por José Matias Delgado, tomo II, Lisboa, Agência Geral das Colónias [1. ${ }^{a}$ ed., 1680].

Castilhon, Jean-Louis (1769), Zingha, reine d'Angola. Histoire africaine en deux parties, Paris, chez Lacombe, Libraire.

Cavazzi von Montecuculo, P. Joanne Antonio (1694), Historische Beschreibung der in dem untern Occidentalischen Mohrenland ligenden drey Königreichen Congo, Matamba, und Angola (...), München, gedruckt und verlegt durch Johann Jäcklin. 
Cavazzi de Montecúccolo, P.e João António (1965), Descrição Histórica dos Três Reinos do Congo, Matamba e Angola. Tradução, notas e índice pelo P. e Graciano Maria de Leguzzano, OP. M. Cap., Lisboa, Junta de Investigações do Ultramar, 2 vols.

Cornicelius, Max (1905), “Romanische Einflüsse in Gottfried Kellers Dichtung”, in Festschrift Adolf Tobler zum siebzigsten Geburtstage, Braunschweig, Georg Westermann, 117-136.

Delille, Karl Heinz (1991), "Rhetorik und Ideologie in der literarischen Übersetzung am Beispiel der portugiesischen Fassung von Kellers Don Correa”, in Erna Pfeiffer / Hugo Kubarth (eds.), Canticum Ibericum. Neuere spanische, portugiesische und lateinamerikanische Literatur im Spiegel von Interpretation und Übersetzung. Georg Rudolf Lind zum Gedenken, Frankfurt am Main, Vervuert Verlag, 111-122.

Delille, Maria Manuela Gouveia (1988), “Uma novela suíça sobre um herói português: Don Correa de Gottfried Keller", Runa. Revista Portuguesa de Estudos Germanísticos, n.o 9-10, 2945.

Doering, Sabine (2007), “Die Politik der schwarzen Dame. Die Inszenierung des imperialen Afrika in Gottfried Kellers Novelle Don Correa", in Jean-Marie Valentin (ed.), Akten des XI. Internationalen Germanistenkongresses Paris 2005 “Germanistik im Konflikt der Kulturen", Bd. 9, Bern, Peter Lang, 49-54.

Dunker, Axel (2008), Kontrapunktische Lektüren. Koloniale Strukturen in der deutschsprachigen Literatur des 19. Jahrhunderts, München, Wilhelm Fink Verlag.

Ermatinger, E. (61924), Gottfried Kellers Leben, Briefe und Tagebücher, Bd.1, Stuttgart / Berlin, Cotta, [1. ed., 1916].

Frenzel, Elisabeth (2005), "Pygmalion”, in E. F., Stoffe der Weltliteratur. Ein Lexikon dichtungsgeschichtlicher Längsschnitte. 10., überarb. und erw. Auflage, Stuttgart, Kröner Verlag, 767-771.

Guthke, Karl (2001), "Der Kanon und die weite Welt. Das außereuropäisch Fremde in der deutschsprachigen erzählenden Literatur des 19. Jahrhunderts”, Jahrbuch Deutsch als 
Fremdsprache 27, 15-70.

Hart, Gail K. (1996), "The Conqueror and His Land-ladies in Keller's Don Correa: GeoGalatea or the Wrath of Nzinga", in Burkhardt Krause / Ulrich Schreck (eds.), Verleiblichungen. Literatur- und kulturgeschichtliche Studien über Strategien, Formen und Funktionen der Verleiblichung in Texten von der Frühzeit bis zum Cyberspace, St. Ingbert, Röhrig Universitätsverlag, 133-148.

Heintze, Beatrix (1996), Studien zur Geschichte Angolas im 16. und 17. Jahrhundert: ein Lesebuch, Köln, Köppe.

Heywood, Linda M. / Thornton, John K. (2007), Central Africans, Atlantic Creoles, and the Foundation of the Americas, 1585-1660, Cambridge, New York, Cambridge University Press.

Keller, Gottfried (1934), Das Sinngedicht. Novellen, in G. K., Sämtliche Werke in 24 Bänden, elfter Band, ed. Jonas Fränkel, Bern und Leipzig, Verlag Benteli A.G.

-- (1960), Dom Corrêa (D. Salvador Corrêa de Sá). Novela traduzida do alemão pelo Prof. Doutor Cordeiro Ramos, Lisboa, Guimarães Editores.

-- (1991), Sieben Legenden. Das Sinngedicht. Martin Salander, in G. K., Sämtliche Werke, Band 6, ed. Dominik Müller, Frankfurt am Main, Deutscher Klassiker Verlag.

-- (1998), Das Sinngedicht, in: G. K., Sämtliche Werke. Historisch-Kritische Ausgabe in 32 Bänden, Band 23.I, Apparat I zu Band 7, ed. Walter Morgenthaler et al., Basel, Stroemfeld Verlag / Zürich, Verlag Neue Zürcher Zeitung.

Neumann, Bernd (1982), Gottfried Keller. Eine Einführung in sein Werk, Königstein/Ts., Athenäum Verlag.

Neumann, Gerhard (1997), “Der Körper des Menschen und die belebte Statue. Zu einer Grundformel in Gottfried Kellers Sinngedicht", in Mathias Mayer / Gerhard Neumann (eds.), Pygmalion. Die Geschichte des Mythos in der abendländischen Kultur, Freiburg im Breisgau, Rombach, 555-591.

Parreira, Adriano (1990), Economia e Sociedade em Angola na Época da Rainha Jinga (Século 
XVII), Lisboa, Editorial Estampa.

Pereira da Silva, J. M. (31868), Os Varões Illustres do Brazil durante os Tempos Coloniaes, 2 vols., Rio de Janeiro, Garnier / Paris, Durand e Pedone-Lauriel (1. ․ ed. 1847 sob o título de Plutarco Brazileiro).

Preisendanz, Wolfgang (1977), Wege des Realismus. Zur Poetik und Erzählkunst im 19. Jahrhundert, München, Fink Verlag.

Rácz, Gabriella (2007), "Die Frau als Fremde: interkulturelle Aspekte in Gottfried Kellers Sinngedicht und Heinrich Manns Zwischen den Rassen", in Csaba Földes / Gerd Antos (eds.), Interkulturalität: Methodenprobleme der Forschung, München, Iudicium, 199-210.

Raeders, Georges (1961), Le "Caramuru" et son traducteur français, Lisboa (tirage à part du Bulletin des Etudes Portugaises, t. XXIII).

Ramos, Gustavo (1920), Uma novela alemã sobre Salvador Correia de Sá, Coimbra, Imprensa da Universidade (Separata do "Boletim da Classe de Letras", vol. XIII, da Academia das Ciências de Lisboa).

Reichert, Karl (1964), "Gottfried Kellers Sinngedicht - Entstehung und Struktur", Germanisch-Romanische Monatsschrift, Bd. XIV, H. 1, Januar, 77-101.

Rosenthal, Angela (2001), “Die Kunst des Errötens. Zur Kosmetik rassischer Differenz”, in Uerlings / Hölz / Schmidt-Lindenhoff (eds.), 95-111.

Silva Corrêa, Elias Alexandre da (1937), História de Angola [escrita provavelmente entre 1787 e1799], vol. I, Lisboa, Editorial Ática.

Straub-Fischer, Esther (1973), Die Farben und ihre Bedeutung im dichterischen Werk Gottfried Kellers, Bern, Francke Verlag.Uerlings, Herbert / Hölz, Karl / Schmidt-Lindenhoff, Viktoria (eds.) (2001), Das Subjekt und die Anderen: Interkulturalität und Geschlechterdifferenz vom 18. Jahrhundert bis zur Gegenwart, Berlin, Erich Schmidt Verlag.

Uerlings, Herbert (2001), "Das Subjekt und die Anderen. Zur Analyse sexueller und kultureller Differenz. Skizze eines Forschungsbereichs", in Uerlings / Hölz / Schmidt- 
Lindenhoff (eds.), 19-53.

Wiesmann, Louis (1983), "Nachwort", in Gottfried Keller, Das Sinngedicht, Ditzingen, Reclam, 309-328.

Zimmermann, Eberhard A. W. (1802), Taschenbuch der Reisen oder unterhaltende Darstellungen der Entdeckungen des 18. Jahrhunderts, in Rücksicht der Länder, Menschen und Produktenkunde. Für jede Klasse von Lesern, Leipzig bei Gerhard Fischer d. Jüng..

Maria Manuela Nobre Gouveia Delille é Professora catedrática jubilada da Faculdade de Letras da Universidade de Coimbra. Orientadora científico-pedagógica dos Grupos de Estudos Germanísticos das Universidades do Porto (1982-1987) e de Aveiro (1988-1993). Fundou, em 1994, o Centro Interuniversitário de Estudos Germanísticos (CIEG), de que foi coordenadora científica até à jubilação em 2006 e no âmbito do qual criou e dirigiu a Colecção Minerva/CIEG (19 vols.) e a série cadernos do cieg (33 vols.). Publicou numerosos estudos sobre Literatura Alemã, Literatura Comparada e Relações Literárias e Culturais Luso-Germânicas, com especial incidência na recepção de autores de língua alemã em Portugal (séculos XVIII, XIX e XX) e de figuras e temas portugueses na literatura de expressão alemã moderna e contemporânea. Em 2004, o Deutscher Akademischer Austauschdienst atribuiu-lhe o «Jacob- und Wilhelm-Grimm-Preis» e, em Maio de 2008, a Universidade do Porto distinguiu-a com o grau de Doutor honoris causa. 


\section{NOTAS}

*Versão refundida e actualizada da comunicação que apresentei no I Colóquio sobre Literatura Suíça, organizado em 1989, sob a direcção de Gonçalo Vilas-Boas, pelo Grupo de Estudos Germanísticos da Faculdade de Letras do Porto, comunicação essa que surgiu publicada num caderno duplo da revista Runa editado com data de 1988 (Delille 1988: 29-45).

${ }^{1}$ Maria Manuela Gouveia Delille escreve de acordo com a antiga ortografia.

${ }^{2}$ Sobre a figura histórica de Salvador Correia de Sá e Benevides existe abundante bibliografia, de que destaco - para além dos capítulos que lhe são dedicados (ou em que é referido) in: Pereira da Silva (31868: 11-150), Silva Corrêa (1937: I, 257-270) e Cadornega (1940: II, 1-68) - o estudo de Charles Ralph Boxer Salvador de Sá and the Struggle for Brazil and Angola 1602-1686 (1952) e, do mesmo autor, o verbete publicado no Dicionário de História de Portugal (1990: 400-401). Veja-se também o artigo de Luís Ferrand de Almeida (1959: 327 330) e respectiva Addenda Corrigenda (1960: 350-351), em que este historiador, apoiado em documentos e seguindo indicações de C. R. Boxer, rejeita a data tradicional de 1688 para o falecimento do herói e opta pela de 1 de Janeiro de 1681.

${ }^{3}$ Das Sinngedicht constitui, aliás, no seu todo, um exemplo típico da chamada Rahmenerzählung [narrativa enquadrada], cujos modelos europeus mais conhecidos são Il Decamerone de Boccaccio e The Canterbury Tales de Chaucer.

${ }^{4}$ A tradução desta e das restantes citações é de minha autoria.

${ }^{5}$ Straub-Fischer (1973: 66-67) e L. Wiesmann (1983: 312) comentam o simbolismo da cor branca e acentuam o carácter romântico da figura de Lúcia e do cenário em que surge inserida. Julgo também que poderia ter interesse uma comparação do quadro traçado por Keller com representações literárias e pictóricas de figuras femininas finisseculares, de forma a evidenciar as fortes semelhanças existentes entre eles, sobretudo se atendermos ao vestuário branco da jovem, à natureza requintada do jardim e ao brilho transfigurador da luz do pôr-do-sol.

${ }^{6}$ Cf. carta de G. Keller ao editor Eduard Vieweg, de 5 de Novembro de 1851, apud Keller 1991: 891.

${ }^{7}$ Note-se que a associação do nome de Galateia à estátua criada por Pigmalião não se encontra em Ovídio, mas aparece pela primeira vez nas adaptações setecentistas da célebre história amorosa (Aurnhammer / Martin (eds.) 2003: 92-99, Frenzel 102005: 768-770); leia-se também o artigo de Angela Rosenthal (2001: 95-111), no qual, com base em obras setecentistas da pintura inglesa e em tratados estéticos e cosméticos, se procura demonstrar como o ideal de beleza feminina da época reflectia a beleza marmórea da estátua de Pigmalião, sendo que a valorização da chamada whiteness da mulher e da sua capacidade de se ruborizar surge frequentemente ligada a um discurso rácico empenhado em sublinhar a superioridade moral e espiritual da 
raça branca. Sobre a recepção do mito de Pigmalião e Galateia na obra de Keller e sobre as complexas relações intertextuais de Das Sinngedicht com outras narrativas oitocentistas alemãs de temática análoga, vd.: Anton 1970: 89 ss., Keller 1991: 922-933, Gerhard Neumann 1997: 23-37, 555-591, e Rosenthal 2001: 95-111.

80 modelo para esta personagem poderá Keller tê-lo encontrado nas jovens de ideias emancipadas dos salões literários berlinenses (herdeiros das tradições culturais da Aufklärung, da Klassik e da Romantik), que frequentara em meados do século (Reichert 1964: 83).

9 Existe uma tradução portuguesa da novela, da autoria de Gustavo Cordeiro Ramos, publicada pela primeira vez em 1920 (Ramos 1920: 71-118) - com um estudo introdutório dedicado à literatura suíça em língua alemã, à vida e à obra de G. Keller e ao conteúdo da novela - e reeditada em 1960 (Keller 1960); sobre essa tradução, leia-se a análise crítica de Karl Heinz Delille (1991: 111-122).

10 Julgo aqui oportuna a inserção de uma breve resenha biográfica de Salvador Correia de Sá, que se fundamenta na consulta das obras referidas na nota 2. Salvador Correia de Sá e Benevides nasceu em Cádis, em 1602, filho de Martim de Sá e de sua mulher D. Maria de Mendoza y Benavides. Descendente da antiga família portuguesa dos Sás, entre os quais se contam vários governadores da Baía e do Rio de Janeiro, cedo se notabilizou na carreira das armas, tendo desempenhado um papel decisivo na defesa e libertação de muitas cidades e territórios brasileiros do jugo dos Holandeses. Em 1631 ou 1632 casa com D. Catarina de Ugarte y Velasco, descendente de uma poderosa família aristocrática espanhola fixada na América do Sul, na região da actual Argentina, e empenha-se, durante a primeira metade da década de 30, na guerra contra os indígenas revoltosos nas margens do rio da Prata e do Paraguai. Em 1641, como governador e capitão-geral do Rio de Janeiro, funções que exerce desde 1637, proclama a soberania de D. João IV nesse território. Em 1644 é nomeado almirante das frotas do Brasil e, em 1647, por ocasião de uma das suas vindas a Portugal, é investido no cargo de governador e capitão-geral de Angola e nessa qualidade recaptura em 1648 Luanda, Benguela e São Tomé aos Holandeses e governa pacificamente o território angolano até 1652, data em que regressa ao Rio, onde volta a exercer altos cargos políticos e militares. No ano de 1662 cessa funções como governador do Rio de Janeiro e vem fixar-se em Lisboa. Em 1667, com a deposição do rei Afonso VI, a quem se manteve fiel, cai temporariamente em desgraça, chegando a ser preso. Não tarda, porém, a ser reabilitado, sendo-lhe de novo atribuído o lugar, que até então exercera, de membro do Conselho Ultramarino. Morre em Janeiro de 1681.

${ }^{11}$ Note-se que o tribunal militar instituído pelo almirante poderá também ser enten dido como um tribunal simbólico de autocondenação e total rejeição da paixão cega que, conduzida por ele próprio de modo falso e enganoso, o ligou, qual força diabólica, àquela mulher misteriosa.

12 Por exemplo, no passo relativo à recusa do estribeiro do castelo do Cercal de selar, sem a autorização expressa da sua ama, os dois cavalos que D. Correia escolhera - “ (...) worauf Correa dem Alten (...) eine N. 34 - 06/ 2016 | 347-378 - ISSN 1645-1112 | http:/dx.doi.org/10.21747/16451112/litcomp34a22 
Ohrfeige gab und ihn aus dem Stall warf, nicht sowohl aus Roheit als aus angeborner Matrimonialpolitik, die in diesem ersten Falle ihm ungesucht zu Gebote stand, so wenig er auch auf dem Gebiete schon erfahren war" (ibidem: 288) [depois do que Correia deu uma bofetada ao velho e o atirou para fora da cavalariça, não tanto por rudeza, mas por uma política matrimonial inata, que neste primeiro caso estava sem mais ao seu dispor, por menos experiente que fosse nessa matéria], note-se o tom simultaneamente irónico e benevolente com que o narrador intradiegético procura explicar o desempenho por parte de D. Correia do papel de marido autoritário, que impõe a sua vontade com total desprezo pela da mulher e não hesita em castigar brutalmente a oposição cortês de um velho servidor de D. Feniza.

13 O passo a que me refiro - "Denn war sie schuldiger, weil das Geschöpf_den wahren Menschen in ihm_nicht geahnt hatte, als er, dem es mit der Bestie in ihr gerade so ergangen war?" (ibidem: 301) [Pois seria ela, por não ter pressentido nele o verdadeiro ser humano, mais culpada do que ele a quem sucedeu o mesmo com a fera que nela havia?] - é suprimido na tradução de Gustavo Cordeiro Ramos.

${ }^{14}$ Esta princesa-embaixadora vem a ser mais tarde a temível Zinga Bandi, a 'rainha-guerreira' de Angola, uma das figuras mais conhecidas da história da resistência angolana aos colonizadores. Trata-se de uma personagem histórica que, no correr dos tempos, ganhou contornos míticos, tendo inspirado uma longa série de obras de natureza ficcional, a primeira das quais foi o romance do autor francês Jean-Louis Castilhon, Zingha, reine d'Angola. Histoire africaine en deux parties, publicado em Paris, em 1769, e muito divulgado no meio literário europeu da época, e uma das últimas, em 2014, o romance de José Eduardo Agualusa A Rainha Ginga. E de como os africanos inventaram o mundo.

15 No comentário à novela Don Correa da edição crítica do Deutscher Klassiker Verlag, transcreve-se integralmente o respectivo passo da versão alemã da obra de Cavazzi (Keller 1991: 1015-1021).

${ }^{16}$ Seguindo o biógrafo J. Baechthold, Emil Ermatinger (61924: I, 599-600) relaciona, sem mencionar o poema Caramuru, a personagem kelleriana de Salvador Correia de Sá com as aventuras, mais lendárias do que históricas, narradas acerca de Diogo Álvares Correia, a quem atribui a nacionalidade espanhola. Gustavo Cordeiro Ramos (1920: 66-68) faz uma referência mais alargada ao navegador português quinhentista, comentando o tratamento literário da figura no Caramuru de Santa Rita Durão. Quanto aos dados biográficos de Diogo Álvares Correia e Salvador Correia de Sá, E. Ermatinger (61924: 675) indica como fonte provável de Keller a Nouvelle biographie générale (Paris, Firmin Didot Frères, Éditeurs, 1852), e Jonas Fränkel (1934: 475 476) testemunha a existência dessa obra na Biblioteca Municipal de Zurique. Note-se que no próprio ciclo narrativo Das Sinngedicht, no final do décimo capítulo (Keller 1991: 276-277), a novela Don Correa, muito especialmente a narração do casamento feliz entre um homem rico e poderoso e uma mulher indigente que lhe é oferecida como escrava, surge como fruto da leitura de uma "Heiratsanekdote" encontrada por Reinhart, 
o narrador intradiegético, numa história de viagens marítimas e conquistas do século XVII, ao que tudo indica escrita em língua francesa.

17 Num estudo intitulado Le "Caramuru" et son traducteur français, Raeders (1961: 22-23) refere que a história do poema Caramuru, narrada segundo a tradução de Monglave, se tornou o assunto de uma ópera intitulada Paraguassú. Chronique brésilienne, representada no Teatro Lírico de Paris em 1865.

180 artigo de Max Cornicelius sobre as influências românicas na escrita kelleriana comprova os conhecimentos do autor suíço quanto à língua e à literatura francesas (Cornicelius 1905: 118ss.).

19 São divergentes as opiniões que se encontram expressas em duas obras historiográficas das últimas décadas (Heintze 1996: 122 e 124, e Heywood / Thornton 2007: 125) quanto à apresentação, no relato de Cavazzi, do papel desempenhado pela princesa angolana Zinga Bandi durante a visita a Luanda, e sobre a aura lendária que se teceu à volta da entrevista: enquanto Beatrix Heintze, através da comparação com outras fontes, atribui em grande parte a uma auto-estilização da própria Zinga o excessivo peso político que é atribuído à princesa nesse relato, bem como o empolamento de todo o episódio, Linda Heywo od e John Thornton inclinam-se para dar crédito à versão de Cavazzi, atendendo sobretudo a que ela se baseia em informações que, embora recolhidas na corte da então rainha Zinga quarenta anos depois do acontecimento, provêm de testemunhas oculares da referida cena. Sobre esta matéria, veja-se também Parreira 1990: 185186.

20 Segundo Jonas Fränkel (Keller 1934: 474), foi R. Ischer quem primeiro indicou, em 1915, o livro de viagens de Zimmermann como uma das possíveis fontes para a entrevista com Annachinga, hipótese que a meu ver apresenta grande credibilidade, não só por no relato de Zimmermann a princesa africana surgir com o nome de Anna Xinga ou Xinga (Zimmermann 1802: 68-70), e não simplesmente com o de Zinga ou Zingha, como na versão alemã da narrativa de Cavazzi, mas também por outro eco que daquele mesmo relato se encontra no texto kelleriano (cf. infra nota 21). Também no subcapítulo sobre as fontes da novela pertencente à nova edição histórico-crítica da obra de G. Keller se aponta o livro de viagens como a fonte mais provável do autor suíço para a narração da referida entrevista, transcrevendo-se, tal como na edição de J. Fränkel, a história contada por Zimmermann (Keller 1998: 425-427).

${ }^{21}$ No relato de Zimmermann, porém, a oferta é expressamente referida: “[...] Xinga erhob sich von ihrem Sitze, ihre Sklavin blieb aber noch in der vorigen Stellung. Man machte sie darauf aufmerksam; allein Xinga antwortete: "Sie sey Euch geschenkt; die Schwester und Abgesandtin eines Königs setzt sich nie zweimal auf ein und denselben Sessel; er bleibe bei dem Hause, worin sie sich seiner bedient hat." (Zimmermann 1802: 6970) [Zinga ergueu-se do seu assento, mas a sua escrava manteve-se na posição anterior. Chamaram-lhe a atenção para isso, todavia Zinga respondeu: "Que ela vos seja oferecida; a irmã e embaixadora dum rei nunca se senta duas vezes na mesma cadeira; que fique na casa onde se serviu dela."]. A colação deste e doutros N. 34 - 06/ 2016 | 347-378 - ISSN 1645-1112 | http:/dx.doi.org/10.21747/16451112/litcomp34a22 
passos dos relatos de Cavazzi e de Zimmermann com os trechos correspondentes da novela Don Correa levame a pensar que Keller terá de facto utilizado ambos os textos.

22 Cf. o passo em que Annachinga se pronuncia sobra a futura educação de Zambo: "Wolle er sie aber bei sich behalten, so solle er sie nur mit der Peitsche dressieren, wenn sie zu ungelehrig sei." (Keller 1991: 311) [No caso, porém, de a querer guardar para si, deveria domesticá-la a chicote se ela se mostrasse pouco dócil].

${ }^{23}$ Segundo o relato de Annachinga ao almirante (ibidem: 310-311), a escrava, em seu poder desde os dez anos de idade, descenderia de um povo oriental, provavelmente já extinto, tendo vindo com a mãe para a parte ocidental do continente africano. Baseado em informações transmitidas por Conrad Ferdinand Meyer, Jonas Fränkel, no seu comentário ao aspecto físico da escrava (Keller 1924: 476-477), chama a atenção para o facto de na obra em dois volumes de G. Rohlfs Quer durch Afrika (1875) G. Keller poder ter encontrado várias referências a povos orientais de cor de pele morena que, ao atravessar, por migração ou rapto, o continente africano, foram ter a zonas habitadas por negros, sendo, portanto, de admitir que Zambo representasse um tipo étnico realmente existente naquela região.

${ }^{24}$ Neste sentido, leia-se também Rosenthal 2001: 95-117, Doering 2007: 52, e Rácz 2007: 202.

250 motivo do baptismo de uma mulher indígena poderá Keller tê-lo encontrado tanto no poema Caramuru, onde no Canto VII se narra o baptismo em França da índia Paraguaçu, como no relato de Cavazzi sobre a princesa africana Zinga, segundo o qual esta, durante a estada em Luanda após a célebre audiência, recebe instrução na religião cristã e vem a ser baptizada com o nome de Ana, tendo como padrinho o governador português João Correia de Sousa e sua mulher D. Ana Correia de Sousa (Cavazzi 1694: 679). Cf. Figura 6.

26 Ursula Amrein (2007: 148) sublinha a duplicidade criada por Keller através deste diálogo, que, por um lado, confirma expressamente o papel semelhante ao de um deus que D. Correia assume na relação amorosa com Zambo/Maria e, por outro, também dele ironicamente se distancia.

${ }^{27}$ Karl S. Guthke (2001: 49-50), que considera o gesto final de Maria como tentativa (submissa) de sossegar D. Correia, insatisfeito com a resposta (de que ela, a sua criatura, não tivera livre escolha), acentua a este propósito o facto de a 'humanização' e educação de Zambo/Maria pelo conquistador-colonizador português constituir um processo de europeização em que a identidade do Outro é praticamente anulada.

${ }^{28}$ Neste sugestivo comentário de Bernd Neumann à problemática sexual e feminina da novela Don Correa são, todavia, de estranhar algumas inexactidões relativas ao tempo e lugar da acção, bem como à nacionalidade do herói. Efectivamente, a novela não decorre no século XVI, como aquele crítico refere (ibidem: 254), mas sim na primeira metade e em meados do século XVII; quanto ao lugar da acção, B. Neumann (ibidem: 254, 255, 256) fala sempre de Espanha, o que, se se torna aceitável no que toca à primeira fase da novela (que é possível situar por volta de 1638, i. e., ainda sob o domínio filipino), não é válido quanto à segunda parte; esta última 
passa-se em Portugal, na época da Restauração, durante o reinado de D. João IV: em 1648, data da Reconquista de Angola aos Holandeses (cf. Keller 1991: 302), e no período imediatamente posterior. Também considero que a designação de D. Correia por "spanischer Grande" (B. Neumann 1982: 254) não respeita nem a verdade histórica nem a ficcional, já que o autor suíço atribui sempre ao herói, de forma correcta, a nacionalidade portuguesa (cf. Keller 1991: 278, 302-303).

${ }^{29}$ Também neste aspecto, as duas cores - branco e vermelho - , que se combinam desde o princípio na figura de Zambo/Maria (ibidem: 308-309), permitem vê-la como figura paralela de Lúcia e acentuam a relação especular entre a intriga amorosa da narrativa emoldurante do ciclo e a da segunda parte da novela Don Correa.

${ }^{30}$ Sobre o condicionalismo económico-político que determinou naquela época tanto a acção dos colonizadores portugueses como a dos governantes africanos, nomeadamente a da rainha Ginga, e sobre o intenso comércio de escravos então praticado no interesse de ambas as partes, leia-se Parreira 1990: 175-201.

${ }^{31}$ Recorde-se, e.g., o qualificativo "gebleicht" para caracterizar, de forma depreciativa, a raça branca (Keller 1991: 309, e supra, p. 356) e leia-se também o passo em que se descreve a pose majestática da princesaembaixadora Annachinga - "Sie saß nach abendländischer Weise auf ihrem Sitze, eine kalte Unbeweglichkeit zur Schau tragend, von welcher manche große Frau des Okzidents hätte lernen können." [Vinha sentada à maneira ocidental, aparentando uma fria impassibilidade, que poderia servir de lição a muitas grandes senhoras do Ocidente.] (Keller 1991: 304) - ou aquele em que se compara o régulo angolano com os burgueses europeus no que concerne ao pedido de ajuda a uma mulher em questões de difícil negociação (Keller 1991: 303). Neste sentido, também Gail K. Hart (1996: 142) põe em relevo as várias equivalências ou semelhanças que se estabelecem na narrativa kelleriana entre a sociedade europeia e a africana, como por exemplo entre as figuras de D. Feniza do Cercal e a princesa Annachinga de Angola na reacção ao autoritarismo de D. Correia, ou entre Annachinga e os jesuítas relativamente à transformação física mutiladora de Zambo, que tanto a princesa angolana como os missionários se propunham.

32 A este respeito, leia-se Gerhard Neumann (1997: 581-583), que, fugindo à interpretação tradicional do referido episódio, vê no desenlace frustrante da história para o jovem capitão francês, não um logro deliberado da bela índia, a quem ele ingenuamente atribuíra uma simplicidade selvagem, mas um desentendimento gerado por diferentes modelos de conquista amorosa. 